\title{
A COMPREHENSIVE INFORMATIVE NOTE ON ASCITES
}

\author{
NAVNEET SINGH ${ }^{*}$, SAZAL PATYAR ${ }^{2}$, NAVEEN CHANDRA TALNIYA ${ }^{1}$
}

${ }^{1}$ Department of Chemistry, School of Chemical Engineering and Physical Science, Lovely Professional University, Phagwara, Punjab, India. ${ }^{2}$ Departmentof Pharmaceutical Sciences, School of Pharmaceutical Science, Lovely Professional University, Phagwara, Punjab, India. Email: drnavneet10@gmail.com

Received: 05 October 2017, Revised and Accepted: 27 December 2017

\begin{abstract}
Ascites impairs both the physical and mental dimensions of quality of life in patients. The patients due to unawareness do not report to medical practitioners in the early stage of disease, and also in few cases, medical practitioners due to lack of adequate expertise face difficulty to ensure the early stage detection for causes of ascites, i.e., due to cirrhosis, cancer, congestive heart failure, mycobacterium tuberculosis, or others. Ascites is a symptom of progression of single disease or multiple diseases. Gross collection of fluid in peritoneal cavity may initiate a series of problems such as spontaneous bacterial peritonitis and an increase in abdominal distension and discomfort and hinder the mobility of the patient and dullness and loss of appetite. In the present review, a detail study over the ecology of ascites has been done with emphasizing on diagnosis by history and physical examination, clinical examination, and imagining techniques followed by management of treatment through general guidelines, and various available therapies are covered.
\end{abstract}

Keywords: Ascites, Malignant, Benign, Imaging techniques, Peritoneal, Ascetic fluid.

(C) 2018 The Authors. Published by Innovare Academic Sciences Pvt Ltd. This is an open access article under the CC BY license (http://creativecommons. org/licenses/by/4. 0/) DOI: http://dx.doi.org/10.22159/ajpcr.2018.v11i4.22948

\section{INTRODUCTION}

The diagnostic paracentesis is usually a clinical tool to find and confirm ascites, but abdominal sonography helps to detect an amount of fluid as little as $100 \mathrm{ml}$ [1]. Normally, $50 \mathrm{ml}$ of fluid in peritoneal cavity gives lubrication, but the accumulation of at least $1500 \mathrm{ml}$ of fluid may be required for clinic evidence. Ascites is known to be the cause of various diseases. Ovarian, endometrial, breast, esophageal, gastric, colorectal, lung, pancreatic, hepatobiliary, and primary peritoneal carcinomas are cancer-related cases which cover $10 \%$ of all cases of ascites [2-4]. The identification of subclinical metastases through cytological investigation of peritoneal fluid was first proposed in 1956 [5]. Thereafter, peritoneal fluid cytology was included in protocol for the staging of ovarian cancer by recommendation of the International Federation of Gynecologists and Obstetricians [6]. However, both false-negative and false-positive rates of peritoneal fluid cytology are high [7]. In general, clinically evident malignant ascites has an association with poor prognosis, regardless of factors [8]. It is not a trusted prognostic indicator, with reported median survival time ranging from 1 to 4 months [9]. Therefore, it is an urgent need for incorporating new diagnostic methods in protocol to detect microscopic disease in peritoneal cavity.

In the present study, an effort has been made to write a comprehensive information note on ascites by incorporating various aspects related to diseases born ascites, possible cause, clinical tests, and management of treatment and role of chemotherapeutic agents.

\section{DIAGNOSIS OF ASCITES}

Ascites may be one of the revelations of a primary disease or symptom of a complication of disease. Simple test(s) and analysis on ascitic fluid (AF) or serum can be of immense help in differentiating benign and malignant causes of ascites. Lots of expertise is required to discriminate malignant from benign causes of ascites. The differential diagnosis of ascites is of paramount importance because therapy and management of two groups are radically different. The protocol for diagnosis of ascites is established according to Fig. 1.

History and physical examination

Proper investigation of physical examination and patients' lifestyle reveals possible cause of ascites. Mild AF may not reflect any symptoms.
Abdominal distension and weight gain are generally observed in case of moderate ascites. Whereas, symptoms such as abdominal discomfort and hindering mobility in patients are produced in case of a large amount of fluid accumulated in peritoneal cavity.

Cirrhosis of liver may be correlated by intensive examination of patient's habits and lifestyle related to alcohol intake, drug abuse, blood transfusions, or hepatitis. Patient may be prone to complications related to liver disease, including refractory ascites, SBP, hyponatremia, or hepatorenal syndrome if they have cirrhosis and ascites [10]. Cardiac ascites may be correlated with heart failure and pericardial disease in patients. A history of malignancy, for example, ovaries, breast, prolonged fever, and chronic pancreatitis may indicate malignant, tubercular etiology, and pancreatic ascites, respectively. Refractory ascites may be correlated with inability to mobilize ascitic fluid or multiple early recurrences of ascites despite giving medical therapy in patients $[10,11]$.

The exact diagnosis of ascites-based diseases is a challenge to the medical practitioners. The experienced gastroenterologists may diagnose mild and moderate ascites with a probability of $50 \%$ through physical examination [12]. It reveals distended abdomen, flank dullness, shifting dullness, and fluid thrill. Flank dullness is the most critical physical sign and has been reported by $90 \%$ of patients, but shifting dullness is more specific. Large ovarian or hydatid cyst, pregnancy with hydromnias, and focal ascites may be the other cases responsible for fluid thrill other than ascites.

\section{Clinical investigations}

\section{Abdominal paracentesis and analysis of $A F$ and non $A F$}

The diagnosis resulted from physical examination and history is further verified by the outcome of the clinical investigation. The different diagnosis of ascites as displayed in Fig. 2 can be predicted effectively by the help of different clinical methodologies as outlined in Fig. 3.

Medical practitioners may evaluate a patient in an early stage by adopting a protocol for abdominal paracentesis and a careful analysis of AF. An investigation under few reported parameters such as physical investigation (peritoneal fluid), serum protein, serum ascites albumin 
gradient, cell count and cytology, AF glucose, ascetic fluid lactate dehydrogenase, serum cholesterol, serum ferritin, and cancer antigen may provide useful information about the possible cause of ascites. Literature findings reveal that peritoneal fluid examination may lead to suggest conventional diagnostic procedures for primary ovarian cancer if molecular abnormalities are detected in peritoneal fluid [13]. By convention, total protein content in peritoneal fluid gives information about exudate or transudate which may further explore pleural fluid and different processes of fluid formation [14]. The cutoff values are generally used in a range between 25 and $30 \mathrm{~g} / \mathrm{L}$ [15-17]. The exudate/transudate concept in ascites evaluation has, however, associated with many problems and exceptions. Therefore, exudates/transudate-based classification was proposed to be discontinued more than 15 years ago [18]. Peritoneal fluid collected from patient with reported ascites of unknown origin may be examined for tests as presented in Table 1 [11,19-23].

However, AF cytology is positive only in validating of peritoneal carcinomatosis. $96.7 \%$ sensitivity of cytology has been reported in detecting peritoneal carcinomatosis if three samples (from different paracentesis procedures) are collected and processed promptly; the first sample is positive in $82.8 \%$, and at least 1 of 2 samples is positive in $93.3 \%$ [24]. In addition to that, the aim of abdominal paracentesis should be to provide immediate relief to the patient while at the same time, preventing complications such as paracentesis-induced circulatory dysfunction (PICD). It may occur after large-volume paracentesis $(>5-6 \mathrm{~L})$ and result in faster reaccumulation of ascites, hyponatremia, renal impairment, and shorter survival [25]. Largevolume paracentesis may lead up to $80 \%$ incidences of PICD without additional therapeutic management; further, the cases may be reduced to $15-35 \%$ with volume expanders [26].

\section{Role of imaging}

Radiologic studies are a boon in the management of ascites because it has been quite successful in detecting a small amount of ascetic fluid as well as helpful in assessing etiology of ascites as shown in Fig. 4.

The possible outcome of physical examination and clinical investigation undergoes intensive cross-examination by the imaging techniques. Abdominal sonography may be used to detect as little as $100 \mathrm{ml}$ of intraperitoneal fluid. Few imaging technique has been listed in Table 2 [27].

\section{Laparoscopy}

Laparoscopy may prove useful technique for direct visualization of peritoneum and other organs if no clear perception for diagnosis is made. In the extreme cases, definite diagnosis may be sorted with biopsies.

\section{MANAGEMENT OF ASCITES}

In the present era of modern technology and advanced drugs, exact diagnosis of ascites is still put a question mark, and exact treatment with efficacy and less toxicity is still undergoing research and study. The management of ascites depends on the possible cause. The protocol to be followed requires intensive screening of factors such as medical practitioners' understanding about patient's health, ascites type, disease, and the stage.

\section{General guidelines for the treatment}

The general guidelines for the treatment of ascites are discussed with the help of Table 3 [28-30].

\section{Medication for ascites}

Apart from dietary sodium restriction, diuretic, and antibiotic, paracentesis should not be considered as first-line therapy in ascites management. The common drugs used for management of ascites are listed in Table 4. The specific treatment with medication is only possible, once the actual causes and type of ascites are confirmed, clinically.

The literature review suggested that prescription of few treatment regimens should be addressed with utmost care due to negative impacts in patients. Drugs which function toward inhibition of vasoconstrictors such as vasopressin, angiotensin, and aldosterone would be expected to lower blood pressure [53]. Lowering blood

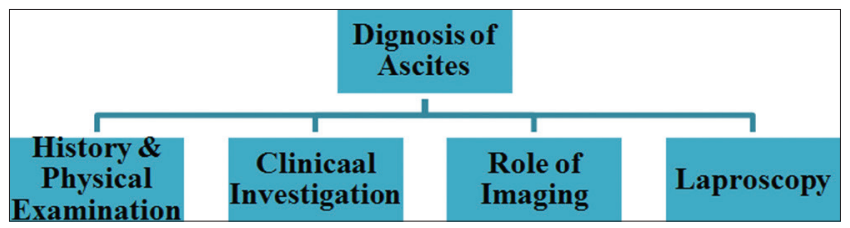

Fig. 1: Protocol for diagnosis of ascites

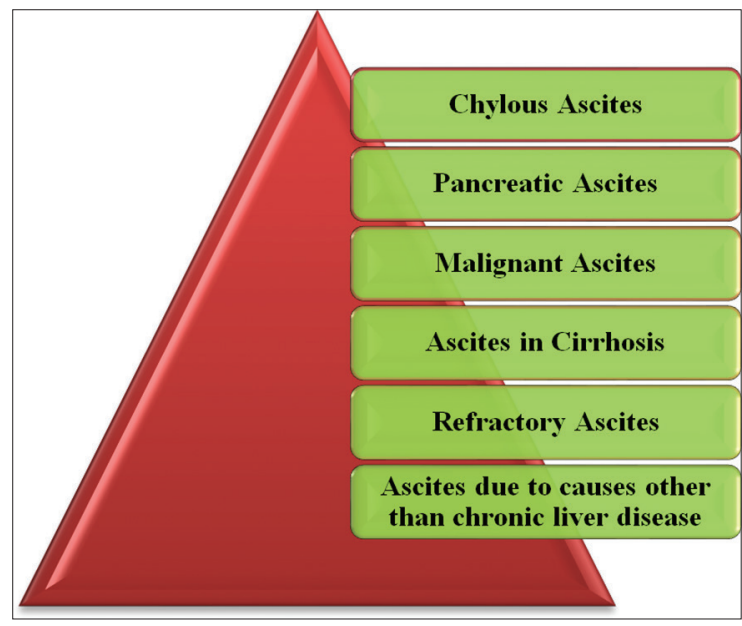

Fig. 2: Classification of ascites

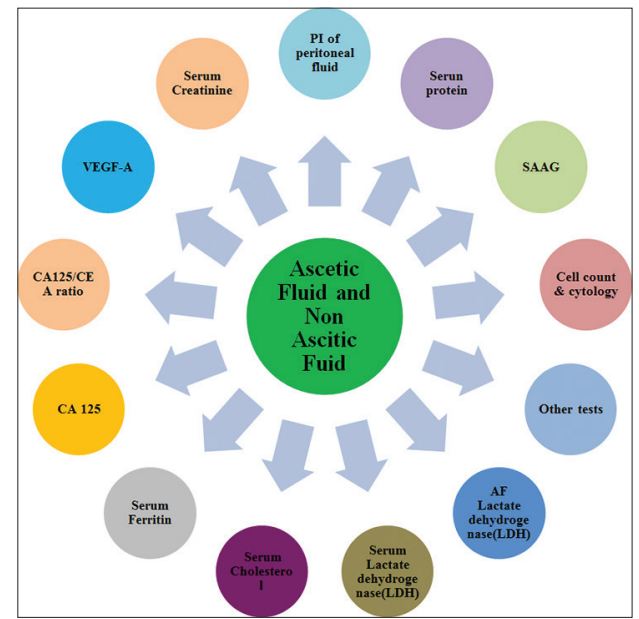

Fig. 3: Clinical methodologies for the diagnosis of ascites

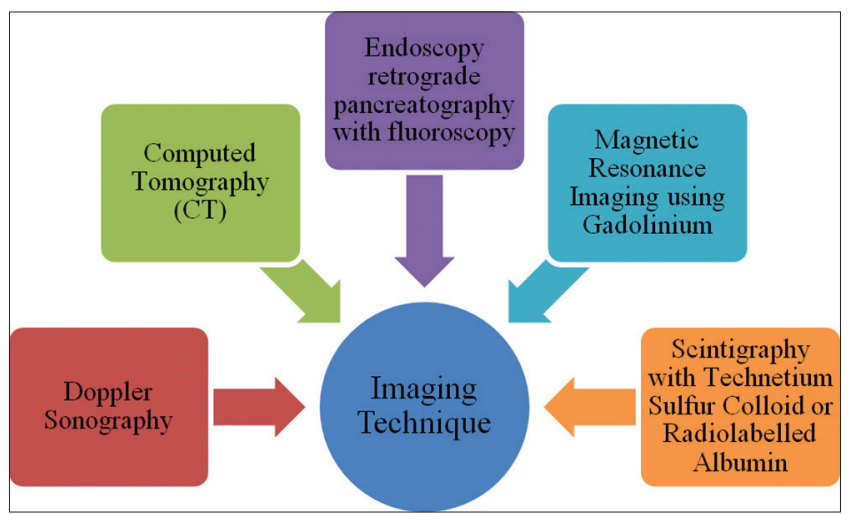

Fig. 4: Imaging techniques 
Table 1: Test for the diagnosis of ascites

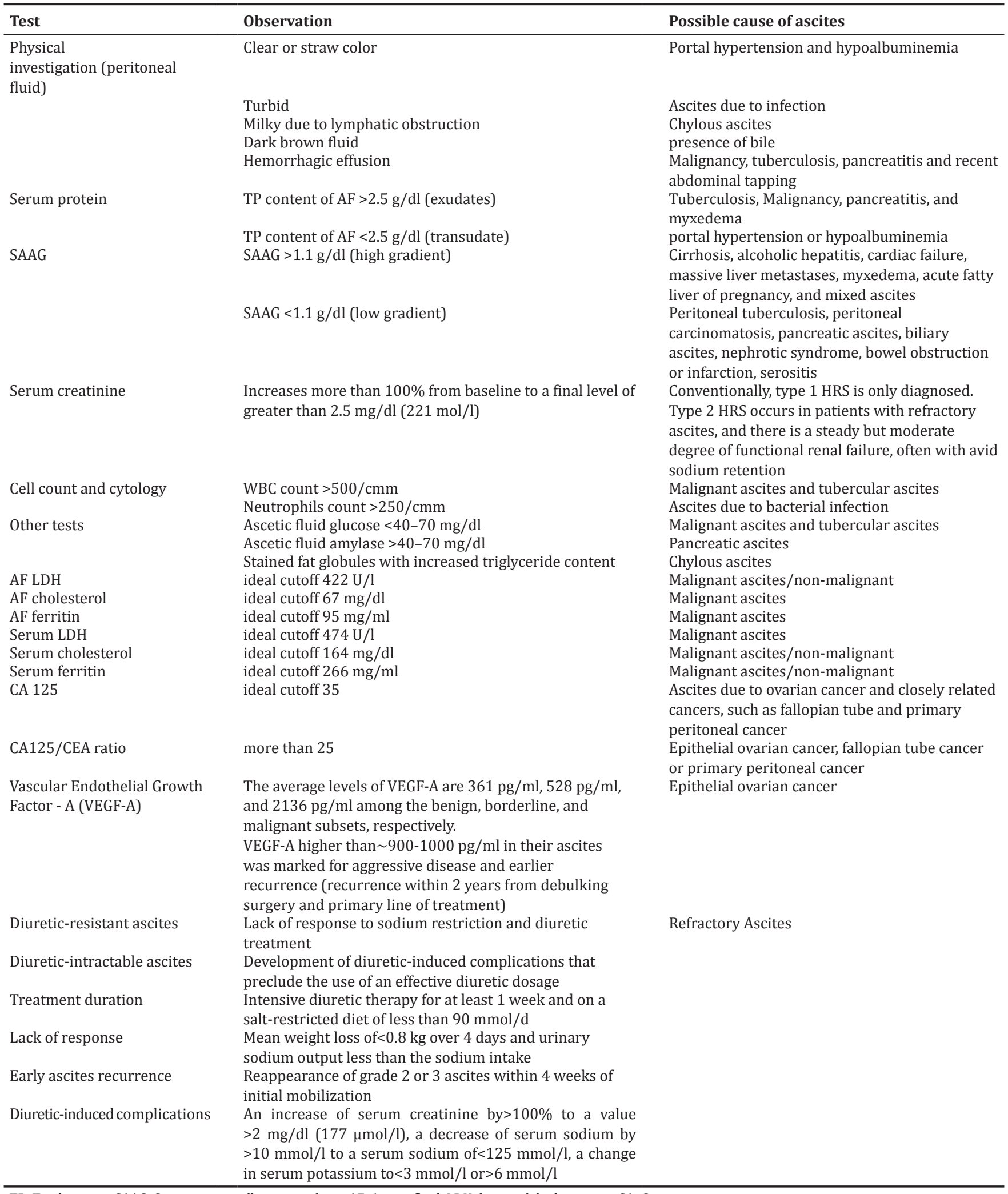

TP: Total protein, SAAG: Serum-ascites albumin gradient, AF: Ascitic fluid, LDH: lactate dehydrogenase, CA: Cancer antigen

pressure might raise survival issues. Cirrhosis and ascites patient should not be prescribed angiotensin-converting enzyme inhibitors and angiotensin receptor blockers or advised with utmost caution.
The European Association for the study of the liver practice guideline on ascites recommends that "they should generally not be used in patients with ascites" [54]. Beta blockers may pose challenges like 
Table 2: Imaging technique for diagnosis of ascites

\begin{tabular}{|c|c|c|}
\hline Imaging technique & Application of detecting & Cause of malignancy \\
\hline Doppler sonography & Thrombosis of the portal or hepatic veins & \\
\hline \multirow[t]{5}{*}{$\mathrm{CT}$} & Appearance of liver & Cirrhosis \\
\hline & Pancreatic pseudo cyst & Pancreatic ascites \\
\hline & Intra-abdominal tumors & Carcinomatosis \\
\hline & $\begin{array}{l}\text { Thickening of mesentery and bowel wall, } \\
\text { matting of bowel loops, and presence of } \\
\text { mesenteric lymph nodes }\end{array}$ & Tuberculosis peritonitis \\
\hline & Peritoneal lining by contrast-enhanced CT scan & Carcinomatosis or inflammatory peritonitis \\
\hline $\begin{array}{l}\text { Magnetic resonance imaging using } \\
\text { gadolinium }\end{array}$ & Peritoneal lining & Carcinomatosis or inflammatory peritonitis \\
\hline $\begin{array}{l}\text { Endoscopy retrograde } \\
\text { pancreatography with fluoroscopy }\end{array}$ & $\begin{array}{l}\text { Leakage of pancreatic juice from the pancreatic } \\
\text { duct }\end{array}$ & $\begin{array}{l}\text { Pancreatic ascites alone or associated with liver } \\
\text { cirrhosis }\end{array}$ \\
\hline $\begin{array}{l}\text { Scintigraphy with technetium } \\
\text { sulfur colloid or radiolabelled } \\
\text { albumin }\end{array}$ & Intraperitoneal origin of the thoracic fluid & Cirrhosis and large hydrothorax \\
\hline
\end{tabular}

CT: Computed tomography

Table 3: General guidelines for the treatment of ascites

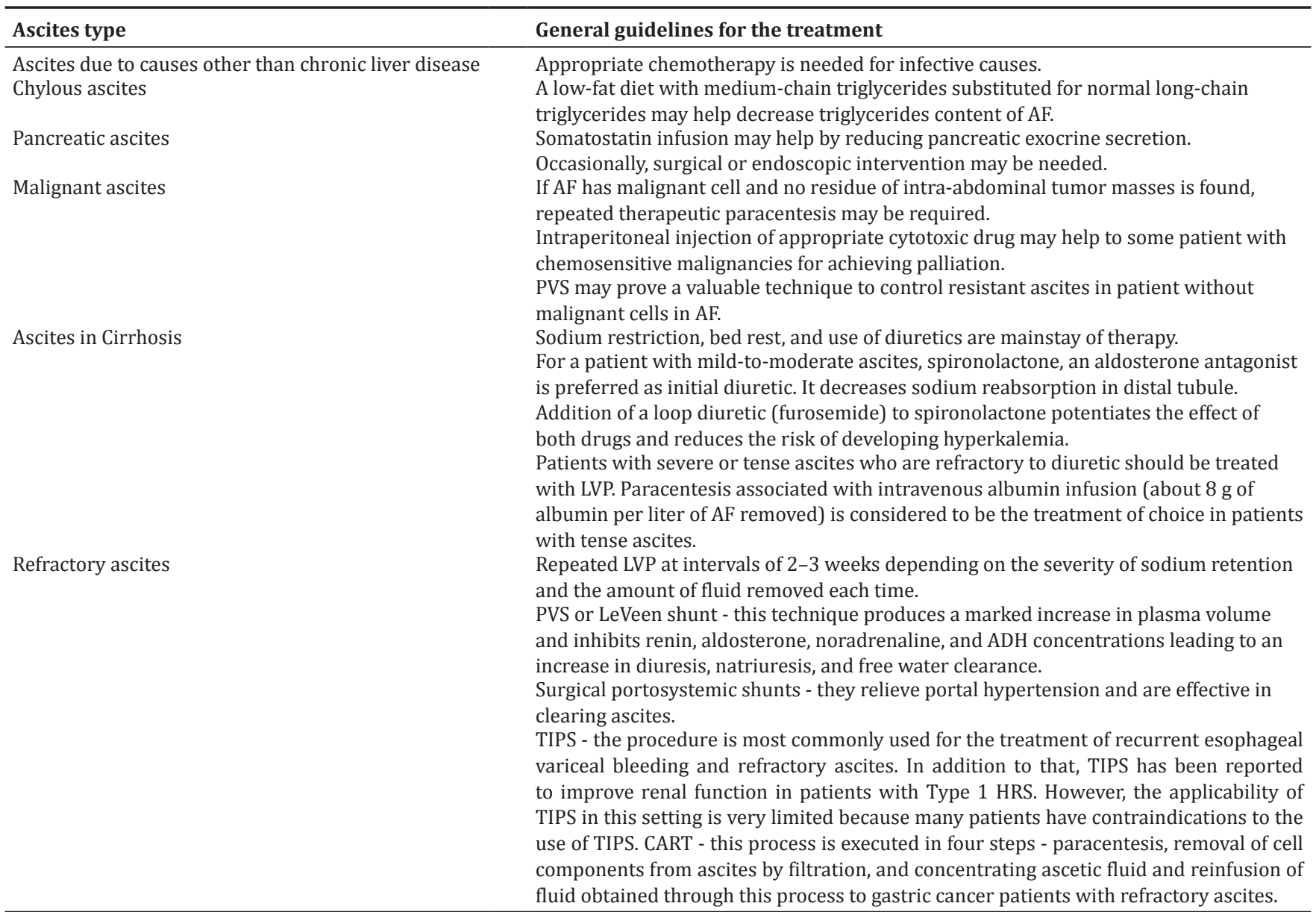

CART: Concentrated ascites reinfusion therapy, TIPS: Transjuglar intrahepatic portosystemic shunts procedure, HRS: Hyponatremia or hepatorenal syndrome, ADH Antidiuretic hormone, PVS: Peritoneovenous shunt, LVP: Large volume paracentesis

shorten survival in refractory ascites. Propranolol has been found to shorten survival in patients with refractory ascites in a panorama study [55]. It may be related with a negative impact on blood pressure and increase in rate of PICD in patients who rely on propranolol intake for management of refractory ascites [56]. In addition to said drugs, different plant-derived extracts are also reported to have anticancer activity in related ascites $[57,58]$.

\section{CONCLUSION}

This study exposes various aspects of ecology of ascites and indicates that the role of history and physical examination, clinical investigation, and imaging techniques followed by laparoscopy is equally important to search possible cause of ascites based diseases. This comprehensive information note provides a wide spectrum of guidelines through 
Table 4: Drugs for the treatment of ascites

\begin{tabular}{lll}
\hline Treatment regimen & Drugs & Reference \\
\hline Diuretic & $\begin{array}{l}\text { Spironolactone and } \\
\text { furosemide }\end{array}$ & {$[31,32]$} \\
& Amiloride & {$[33]$} \\
& Triamterene, metolazone, & {$[34-36]$} \\
& and hydrochlorothiazide & \\
& Midodrine & {$[37]$} \\
& Cephalosporin plus & {$[38,39]$} \\
& vancomycin or cloxacillin & \\
& Norfloxacin & {$[40-46]$} \\
Antibiotic & Trimethoprim & \\
& Sulfamethoxazole & \\
& Cefotaxime, ampicillin plus & {$[47]$} \\
& tobramycin & \\
& Tolvaptan & {$[48,49]$} \\
VAPTANS & Satavaptan & {$[50]$} \\
Chemotherapeutic & Carboplatin and & {$[51]$} \\
agents & gemcitabine & \\
& Paclitaxel, carboplatin, and & {$[52]$} \\
& liposomal doxorubicin & \\
\hline VAPTANS: Vasopressin receptorantagonists &
\end{tabular}

which ascites may be diagnosed. The successful management of ascites depends on the successful diagnosis of the cause. The study further presents a panorama of treatment and therapies in an array of benign and malignant ascites.

\section{ACKNOWLEDGMENT}

The authors express sincere gratitude to the patients for sharing their experiences during treatment of their disease. Authors also express their regard to Dr. Lalit Kumar Professor and HOD, Dr. Anita, and other doctors, Department of Medical Oncology, Dr. B. R. Ambedkar InstituteRotary Cancer Hospital, AIIMS, New Delhi, India, and also other medical experts in this field for their esteem guidance.

\section{AUTHOR CONTRIBUTIONS}

Dr. Navneet Singh: Study design, planning, interpretation of data, manuscript writing and approval of the version to be published. Dr. Sazal Patyar and Dr. Naveen Chandra Talniya: Interpretation of data and approval of the version to be published.

\section{CONFLICT OF INTEREST}

The authors declare that they have no conflict of interest.

\section{REFERENCES}

1. Thoeni RF. The role of imaging in patients with ascites. AJR Am J Roentgenol 1995;165:16-8.

2. Runyon BA. Care of patients with ascites. N Engl J Med 1994;330:337-42.

3. Parsons SL, Watson SA, Steele RJ. Malignant ascites [Review]. Br J Surg 1996;83:6-14.

4. Runyon BA, Hoefs JC, Morgan TR. Ascitic fluid analysis in malignancy-related ascites. Hepatology 1988;8:1104-9.

5. Creasman WT, Rutledge F. The prognostic value of peritoneal cytology in gynecologic malignant disease. Am J Obstet Gynecol 1971;110:773-81.

6. Tobias JS, Griffiths CT. Management of ovarian carcinoma. N Engl J Med 1976;294:818-23.

7. Motherby H, Nadjari B, Friegel P, Kohaus J, Ramp U, Böcking A, et al. Diagnostic accuracy of effusion cytology. Diagn Cytopathol 1999;20:350-7.

8. Ayantunde AA, Parsons SL. Pattern and prognostic factors in patients with malignant ascites: A retrospective study. Ann Oncol 2007;18:945-9.

9. Spratt JS, Edwards M, Kubota T, Lindberg R, Tseng MT. Peritoneal carcinomatosis: Anatomy, physiology, diagnosis, management. Curr Probl Cancer 1986; 10:558-84.

10. Moore KP, Wong F, Gines P, Bernardi M, Ochs A, Salerno F, et al. The management of ascites in cirrhosis: Report on the consensus conference of the international ascites club. Hepatology 2003;38:258-66.

11. Arroyo V, Ginès P, Gerbes AL, Dudley FJ, Gentilini P, Laffi G, et al. Definition and diagnostic criteria of refractory ascites and hepatorenal syndrome in cirrhosis. International ascites club. Hepatology 1996;23:164-76.

12. Cattau EL Jr., Benjamin SB, Knuff TE, Castell DO. The accuracy of the physical examination in the diagnosis of suspected ascites. JAMA 1982;247:1164-6.

13. Paola P, Rachel Z, David S, Theresa N. Molecular analysis of peritoneal fluid in ovarian cancer patients. Mod Pathol 2003;16:636-40.

14. Tarn AC, Lapworth R. Biochemical analysis of pleural fluid: What should we measure? Ann Clin Biochem 2001;38:311-22.

15. Paddock FK. The diagnostic significance of serous fluids in disease. N Engl J Med 1940;223:1010-5.

16. Rovelstad RA, Bartholomew LG, Cain JC, McKenzie BF, Soule EH. Ascites. I. The value of examination of ascitic fluid and blood for lipids and for proteins by electrophoresis. Gastroenterology 1958;34:436-51.

17. Boyer TD, Kahn AM, Reynolds TB. Diagnostic value of ascitic fluid lactic dehydrogenase, protein, and WBC levels. Arch Intern Med 1978;138:1103-5.

18. Runyon BA, Montano AA, Akriviadis EA, Antillon MR, Irving MA, McHutchison JG, et al. The serum-ascites albumin gradient is superior to the exudate-transudate concept in the differential diagnosis of ascites. Ann Intern Med 1992;117:215-20.

19. Maiya M. Diagnosis of Ascites-Pearls and Pitfalls. Available from: http://www.apiindia.org/pdf/medicine_update_2011/67_diagnosis_of_ ascites.pdf. [Last accessed on 2017 Oct 01]

20. Banerjee M, Singh R, Arora MM, Srinivas V, Basannar D, Parikar S. Biomarkers of malignant ascites-a myth or reality. Med J Armed Forces India 2011;67:108-12.

21. Understanding CA 125 Levels: A Guide for Ovarian Cancer Patients. Available from: http://www.foundationforwomenscancer.org/wpcontent/uploads/CA125levels.pdf. [Last accessed on 2017 Oct 01].

22. Yedema CA, Kenemans P, Wobbes T, Thomas CM, Bon GG, Mulder C, et al. Use of serum tumor markers in the differential diagnosis between ovarian and colorectal adenocarcinomas. Tumor Biol 1992;13:18-26.

23. Bhaskari J, Krishnamoorthy L. Impact of ascites and plasma levels of VEGF-A in epithelial ovarian cancers. J Clin Cell Immunol 2015;6:1000353.

24. Runyon BA, Hoefs JC, Morgan TR. Ascitic fluid analysis in malignancy-related ascites. Hepatology 1988;8:1104-9.

25. Lindsay AJ, Burton J, Ray CE Jr. Paracentesis-induced circulatory dysfunction: A primer for the interventional radiologist. Semin Intervent Radiol 2014;31:276-8.

26. Sola-Vera J, Miñana J, Ricart E, Planella M, González B, Torras X, et al. Randomized trial comparing albumin and saline in the prevention of paracentesis-induced circulatory dysfunction in cirrhotic patients with ascites. Hepatology 2003;37:1147-53.

27. Goldberg BB, Goodman GA, Clearfield HR. Evaluation of ascites by ultrasound. Radiology 1970;96:1522.

28. Sood R. Ascites: Diagnosis and Management. Available from: http:// www.medind.nic.in/jac/t00/i1/jact00i1p81.pdf. [Last assessed on 2017 Oct 01].

29. Kozaki K, Takagi T, Fukuda T, Sanpei T, Terunuma Y, Yatabe Y, et al. Safety and effectiveness of cell-free concentrated ascites reinfusion therapy in gastric cancer patients with refractory ascites. Anat Physiol 2017;7:S6.

30. Thuluvath PJ, Bal JS, Mitchell S, Lund G, Venbrux A. TIPS for management of refractory ascites response and survival are both unpredictable. Dig Dis Sci 2003;48:542.

31. Runyon BA. Care of patients with ascites. N Engl J Med 1994;330:33742.

32. Runyon BA. Ascites and spontaneous bacterial peritonitis. In: Feldman M, Friedman LS, Brandt LJ, editors. Sleisenger and Fordtran's Gastrointestinal and Liver Disease. 9 $^{\text {th }}$ ed. Philadelphia, PA: Saunders Elsevier; 2010. p. 1517-41

33. Angeli P, Dalla Pria M, De Bei E, Albino G, Caregaro L, Merkel C, et al. Randomized clinical study of the efficacy of amiloride and potassium canrenoate in nonazotemic cirrhotic patients with ascites. Hepatology 1994;19:72-9.

34. Ginsberg DJ, Saad A, Gabuzda GJ. Metabolic studies with the diuretic triamterene in patients with cirrhosis and ascites. $\mathrm{N}$ Engl J Med 1964;271:1229-35.

35. Hillenbrand $P$, Sherlock $S$. Use of metolazone in the treatment of ascites due to liver disease. Br Med J 1971;4:266-70

36. McHutchison JG, Pinto PC, Reynolds TB. Hydrochlorothiazide 
as a third diuretic in cirrhosis with refractory ascites. Hepatology 1989;10:719.

37. Singh V, Dhungana SP, Singh B, Vijayverghia R, Nain CK, Sharma N, et al. Midodrine in patients with cirrhosis and refractory ascites: A randomized pilot study. J Hepatol 2012;56:348-54.

38. Fernandez J, Acevedo J, Castro M, Orlando G, Carlos R, Daria R, et al. Prevalence and risk factors of infections by resistant bacteria in cirrhosis: A prospective study. Hepatology 2012;55:1551-61.

39. Rongey C, Lim NH, Runyon BA. Cellulitis in patients with cirrhosis and edema: An under-recognized complication currently more common that spontaneous bacterial peritonitis. Open Gastro J 2008;2:24-7.

40. Soriano G, Guarner C, TeixidoM, Such J, Barrios J, Enriquez J, et al. Selective intestinal decontamination prevents spontaneous bacterial peritonitis. Gastroenterology 1991;100:477-81.

41. Gines P, Rimola A, Planas R, Vargas V, Marco F, Almela M, et al. Norfloxacin prevents spontaneous bacterial peritonitis recurrence in cirrhosis: Results of a double-blind, placebo-controlled trial. Hepatology 1990;12:716-24.

42. Singh N, Gayowski T, Yu VL, Wagener MM. Trimethoprimsulfamethoxazole for the prevention of spontaneous bacterial peritonitis in cirrhosis: A randomized trial. Ann Intern Med 1995;122:595-8

43. Rolachon A, Cordier L, Bacq Y, Nousbaum JB, Franza A, Paris JC, et al. Ciprofloxacin and long-term prevention of spontaneous bacterial peritonitis: Results of a prospective controlled trial. Hepatology 1995;22:1171-4

44. Fernández J, Navasa M, Planas R, Montoliu S, Monfort D, Soriano G, et al. Primary prophylaxis of spontaneous bacterial peritonitis delays hepatorenal syndrome and improves survival in cirrhosis. Gastroenterology 2007; 133:818-24.

45. Saab S, Hernandez JC, Chi AC, Tong MJ. Oral antibiotic prophylaxis reduces spontaneous bacterial peritonitis occurrence and improves short-term survival in cirrhosis: A meta-analysis. Am J Gastroenterol 2009; 104:993-1001.

46. Loomba R, Wesley R, Bain A, Csako G, Pucino F. Role of fluoroquinolones in the primary prophylaxis of spontaneous bacterial peritonitis: Meta-analysis. Clin Gastroenterol Hepatol 2009;7:487-93.

47. Felisart J, Rimola A, Arroyo V, Perez-Ayuso RM, Quintero E, Gines P, et al. Randomized comparative study of efficacy and nephrotoxicity of ampicillin plus tobramycin versus cefotaxime in cirrhotics with severe infections. Hepatology 1985;5:457-62.

48. Schrier RW, Gross P, Gheorghiade M, Berl T, Verbalis JG, Czewiec FS, et al. Tolvaptan, a selective oral vasopressin V2-receptor antagonist for hyponatremia. N Engl J Med 2006;355:2099-112.

49. Cardenas A, Gines P, Marotta P, Czerwiec F, Oyuang J, Guevara M, et al. Tolvaptan, an oral vasopressin antagonist, in the treatment of hyponatremia in cirrhosis. J Hepatol 2012;56:571-78.

50. Wong F, Watson H, Gerbes A, Vilstrup H, Badalamenti S, Bernardi M, et al. Satavaptan for the management of ascites in cirrhosis: Efficacy and safety across the spectrum of ascites severity. Gut 2012;61:108-16.

51. Constantin AD, Thomas JH, Doru TA, Carboplatin-gemcitabine in the therapy of advanced ovarian cancer: Dose reduction consideration. J Oncol Pharm Pract 2010;16:63-6.

52. Potamianou A, Androulakis N, Papakotoulas P, Toufexi H, Latoufis C, Kouroussis C, et al. Sequential combination of paclitaxel-carboplatin and paclitaxel-liposomal doxorubicin as a first-line treatment in patients with ovarian cancer. A multicenter phase II trial. Oncology 2005;69:348-53.

53. Pariente EA, Bataille C, Bercoff E, Lebrec D. Acute effects of catopril on systemic hemodynamics and on renal function in cirrhotic patients with ascites. Gastroenterology 1985;88:1255-9.

54. Gines P, Angeli P, Lenz K, Moller S, Moore K, Moreau R. EASL clinical practice guideline on the management of ascites, spontaneous bacterial peritonitis, and hepatorenal syndrome. J Hepatol 2010;53:397-417.

55. Serste T, Melot C, Francoz C, Durand F, Rautou PE, Valla D, et al. Deleterious effects of beta-blockers on survival in patients with cirrhosis and refractory ascites. Hepatology 2010;52:1017-22.

56. Serste T, Francoz C, Durand F, Rautou PE, Melot C, Valla D, et al. Beta-blockers cause paracentesis induced circulatory dysfunction in patients with cirrhosis and refractory ascites: A cross-over study. J Hepatol 2011;55:794-9.

57. Srilatha M, Santhi R, Annapurani S. Anticancer activity of plant protein against Dalton's lymphoma ascites tumor cell lines. Asian J Pharm Clin Res 2017;10:206-10.

58. Sujana N, Ramanathan S, Vimala V, Muthuraman MS, Pemaiah B. Antitumour potential of Passiflora Incarnata.L against Ehrlich ascites carcinoma. Int J Pharm Sci 2012;4:17-20. 